\title{
Sistem Produksi dan Produktivitas Sapi Jawa-Brebes dengan Pemeliharaan Tradisional (Studi Kasus di Kelompok Tani Ternak Cikoneng Sejahtera dan Lembu Lestari Kecamatan Bandarharjo Kabupaten Brebes)
}

\section{Beef Production and Productivity Systems Java-Brebes Cattle Raised Traditionally}

(Case Study at Cikoneng Sejahtera and Lembu Lestari Farmer Groups at Bandarharjo District, Brebes Regency)

\author{
C. M. S. Lestari, E. Purbowati, S. Dartosukarno dan E. Rianto \\ Fakultas Peternakan dan Pertanian Universitas Diponegoro \\ Jl. Prof. H. Soedarto, SH Kampus Tembalang Semarang, 50275 \\ e-mail: cmslest@yahoo.co.id \\ (Diterima: 15 November 2013; Disetujui: 2 Februari 2014)
}

\begin{abstract}
ABSTRAK
Penelitian bertujuan untuk mengkaji sistem produksi dan produktivitas sapi Jawa-Brebes (Jabres) yang dipelihara oleh kelompok tani ternak (KTT) sapi Jabres di Kecamatan Bandarharjo, Kabupaten Brebes. Penelitian menggunakan metode studi kasus melalui observasi, wawancara dan pengukuran di lapangan. Data yang diperoleh diolah dan disajikan secara deskriptif. Hasil penelitian menunjukkan bahwa tujuan pemeliharaan sapi Jabres oleh KTT untuk memperoleh anak sapi sebagai tabungan. Pemeliharaan dilakukan secara tradisional dengan cara menggembalakan sapi-sapi tersebut di hutan maupun pematang sawah pada pagi hari, sedangkan pada sore hari sapi dikandangkan dan diberi tambahan pakan kasar sesuai ketersediaan jenis pakan. Perkawinan terjadi secara alami ketika sapi digembalakan tanpa campur tangan peternak. Anak-anak sapi sebelum sapih (umur 1-4 bulan) mempunyai PBBH sebesar 0,29 $\pm 0,15 \mathrm{~kg}$, sedangkan PBBH anak sapi yang telah disapih (umur 10-11 bulan) hanya 0,27 $\pm 0,17 \mathrm{~kg}$. Kesimpulan penelitian ini ialah $98 \%$ anggota KTT di Kecamatan Bandarharjo melaksanakan sistem produksi induk-anak dengan pemeliharaan semi intensif. Produktivitas anak-anak sapi Jabres sebelum dan setelah sapih cukup baik.
\end{abstract}

Kata kunci : sistem produksi, produktivitas, sapi Jabres, pemeliharaan tradisional

\begin{abstract}
This case study aimed to evaluate the production system and the productivity of Jabres cattle which were raised by group of farmers in Bandarharjo district, Brebes Regency. The gathered data were presented descriptively. The result showed that the purpose of the group of farmer in raising the Jabres cattle were to get the calves as an investment. The Jabres cattle were raised traditionally. During the day farmers brought the Jabres cattle to the forest or to the other places in order to get grasses or shrubs for their food, while in the evening they kept their cattle in stall and fed them with roughage depended on the availability of the roughage. The breeding occurred naturally when the Jabres cattle was herd. The pre weaning calves (1-4 months) had an average daily gain $(A D G)$ of $0.29 \pm 0.15 \mathrm{~kg}$, whereas the $A D G$ of post weaning calves is as high as $0.27 \pm 0.17 \mathrm{~kg}$. It could be concluded that the group of farmers in Bandarharjo district did cow-calf production system traditionally. The productivity of pre and post weaning calves were good enough.
\end{abstract}

Keywords: production system, productivity, Jabres cattle, raised traditionally 


\section{PENDAHULUAN}

Sapi Jawa-Brebes (Jabres) merupakan sapi lokal yang hanya terdapat dan dipelihara oleh masyarakat di beberapa Kecamatan Kabupaten Brebes, Propinsi Jawa Tengah. Sapi Jabres adalah sapi Jawa yang sudah beradaptasi dengan lingkungan Kabupaten Brebes sehingga lebih dikenal dengan nama sapi Jabres. Menurut Rouse (1976), sapi Jawa merupakan sapi yang didomestikasi dari Bos sondaicus atau disebut juga Bos banteng. Dijelaskan lebih lanjut oleh Rouse (1976) bahwa pada jaman dulu, sapi Jawa sangat mudah ditemukan di pulau Jawa, sehingga sering disebut sesuai dengan nama tempat sapi tersebut berada.

Berdasarkan kajian dari Dinas Peternakan Kabupaten Brebes yang bekerjasama dengan BPTP Jawa Tengah (2005), diduga bahwa sapi Jabres merupakan hasil persilangan antara sapi Jawa dengan sapi lokal yang mempunyai bulu coklat seperti sapi Bali dan Madura. Dugaan tersebut sama dengan hasil penelitian Sutopo et al. (2001) yang menunjukkan bahwa jarak genetik sapi Jawa dan sapi Madura lebih dekat, dibandingkan dengan sapi PO. Sapi Jawa tersebut kemudian berkembang biak sehingga morphologis maupun fisiologisnya telah mengalami penyesuaian dengan agro-ekosistem daerah Kabupaten Brebes (Aryogi et al., 2007).

Ciri karakteristik yang dapat dilihat pada sapi Jawa yaitu bentuk tubuh relatif kecil, tidak berpunuk dan tanduk pendek, runcing (Soeroso dan Kurnianto, 2006). Kulit berwarna coklat dengan warna putih pada bagian pantat yang melebar ke arah kaki sehingga membentuk huruf $\mathrm{M}$, warna hitam pada bagian dalam telinga dan terdapat garis hitam di punggung sampai ke ujung ekor (Suroso dan Kurnianto, 2006; Munadi 2010, dan Lestari, 2012). Berdasarkan pengamatan Soeroso dan Kurnianto (2006), Aryogi et al. (2007) dan Lestari (2012), ada 4 variasi warna sapi Jabres, yaitu warna coklat, putih kuning kecoklatan, coklat tua campur putih dan hitam. Semua sapi Jabres mempunyai rambut berwarna hitam di ujung ekor dan sering terdapat warna putih berbentuk belah ketupat di keningnya.

Populasi sapi Jabres pada tahun 2011 sebesar 23.221 ekor, dan sebanyak 3.800 ekor terdapat di Kecamatan Bandarharjo atau $1636 \%$ dari seluruh total populasi sapi Jabres di Kabupaten Brebes (Oktovianto, 2013). Sapi Jabres mempunyai ukuran tubuh yang kecil (200-300 kg) sebagaimana sapi lokal yang lain, namun memiliki keunggulan yaitu persentase karkasnya cukup tinggi, sehingga sangat potensial sebagai sapi potong. Hasil penelitian Lestari et al. (2010) menunjukkan bahwa rata-rata dressing percentage (DP) sapi Jabres sebesar 51,29 $\pm 2,60 \%$. Keunggulan lain yang dimiliki sapi Jabres yaitu calving interval cukup pendek sekitar 11-14 bulan (Aryogi et al., 2007), namun hasil penelitian Oktovianto (2013) menunjukkan bahwa calving interval sapi Jabres sekitar 18-21 bulan. Adapun informasi yang akurat tentang produktivitas sapi Jabres yang lain masih sangat terbatas.

Sistem produksi pada sapi potong dapat dibedakan menjadi 3 (tiga) yaitu sistem produksi induk-anak, pembesaran dan penggemukan (Blakely dan Bade, 1998). Sistem produksi induk anak merupakan sistem produksi untuk menghasilkan anak-anak lepas sapih, yang akan digunakan untuk program selanjutnya, sedangkan sistem pembesaran bertujuan untuk menghasilkan sapi-sapi untuk calon pengganti induk dan pejantan (peremajaan) atau bakalan untuk penggemukan.

Di Indonesia, perbedaan sistem produksi ini tidak jelas, karena peternakan yang dilakukan merupakan usaha sambilan. Biasanya petani memelihara ternak untuk mendapatkan anak yang akan dijual sesuai kebutuhan, atau menggemukkan sapi-sapinya untuk dijual ketika membutuhkan uang, sebagaimana dinyatakan oleh Luanmase et al. (2011) bahwa di Indonesia usaha sapi potong hanya dijadikan sebagai usaha sambilan dengan pemeliharaan tradisional. Petani tidak pernah merencanakan waktu penjualan produknya sehingga ternak dipelihara terus menerus tanpa memperhitungkan untung rugi dalam pemeliharaan ternak sapi tersebut. Meskipun sebagai usaha sambilan, usaha ternak sapi bisa memiliki peran ganda bagi petani yaitu selain sebagai 
tabungan yang sewaktu-waktu dapat diuangkan, bisa juga sebagai sumber pupuk organik (Sukardono, 2005). Penelitian ini bertujuan untuk mengkaji sistem produksi dan produktivitas sapi Jabres yang dipelihara petani peternak di Kelompok Tani Ternak (KTT) Cikoneng Sejahtera dan Lembu Lestari Kecamatan Bandarharjo, Kabupaten Brebes.

\section{METODE}

Penelitian dilakukan dengan metode studi kasus terhadap KTT Cikoneng Sejahtera dan Lembu Lestari yang terdapat di Kecamatan Bandarharjo Kabupaten Brebes untuk mengkaji sistem produksi yang dilakukan KTT tersebut dan produktivitas sapi Jabres. Data diperoleh dengan observasi dan wawancara terhadap anggota kedua KTT tersebut menggunakan kuesioner, serta dari catatancatatan kelompok. Selain itu dilakukan pula penimbangan anak sapi untuk mendapatkan data pertambahan bobot badan harian sebelum dan lepas sapih.

Observasi dilakukan untuk memperoleh gambaran tentang sistem pemeliharaan yang dilakukan oleh KTT meliputi perkandangan, perkawinan dan pemberian pakan. Wawancara dilakukan terhadap 16 peternak anggota KTT Cikoneng Sejahtera dan 21 peternak anggota KTT Lembu Lestari (30\% dari total anggota KTT) untuk memperoleh data tentang pendidikan, pekerjaan, pengalaman beternak, jumlah ternak yang dimiliki dan tujuan bêternak sapi Jabres.

Penimbangan anak sapi dilakukan pada masing-masing kelompok umur sebanyak 15 ekor yang dibedakan menjadi kelompok umur 1-4 bulan (sebelum sapih ) dan yang berumur 10-11 bulan (lepas sapih) untuk mendapatkan data pertambahan bobot badan harian. Data PBBH dihitung selama 3 (tiga) minggu pemeliharaan. Data yang diperoleh ditabulasi dan dianalisis secara deskriptif dengan mencari rata-ratanya menggunakan program Microsoft Excel 2010.

\section{HASIL DAN PEMBAHASAN}

\section{Profil Kelompok Tani Ternak dan Pola Pemeliharaan Ternak di Kecamatan Bandarharjo.}

Ada 2 (dua) kelompok tani ternak yang terdapat di Kecamatan Bandarharjo, yaitu KTT Cikoneng Sejahtera yang ada di Desa Malahayu, dan KTT Lembu Lestari yang terdapat di Desa Cikuya. Keduanya merupakan kelompok tani ternak yang memelihara sapi, khususnya sapi Jabres. Terbentuknya KTT ini dilatarbelakangi adanya program pelestarian sapi Jawa yang keadaannya semakin terpinggirkan, oleh Dinas Peternakan Kabupaten Brebes sekaligus untuk meningkatkan pendapatan masyarakat. Selain kedua KTT tersebut, di Kecamatan Bandarharjo masih terdapat peternak sapi Jabres yang tidak menjadi anggota kelompok tani ternak. Adapun profil KTT Cikoneng Sejahtera dan Lembu Lestari ditampilkan pada Tabel 1.

Berdasarkan Tabel 1, maka dapat diketahui bahwa anggota KTT sudah berpengalaman dalam memelihara sapi Jabres, namun pengalaman yang dipunyai berdasarkan pemeliharaan secara turun temurun. Hal ini sesuai pendapat Munadi (2010) yang menyatakan bahwa peternak di Kabupaten Brebes sudah cukup berpengalaman dalam memelihara sapi potong, namun pola pemeliharaan yang dilakukan masih tradisional, yang ditandai dengan rendahnya jumlah kepemilikan serta terbatasnya keterampilan dan teknologi yang dikuasai. Pendidikan tertinggi, peternak di kedua KTT sebagian besar SLTP, hanya satu peternak di KTT Cikoneng Sejahtera yang berpendidikan sarjana. Pendidikan anggota KTT ini sesuai dengan kondisi umum peternak di Indonesia, khususnya peternakan rakyat sebagaimana pendapat Sonbait et al., (2011).

Pola pemeliharaan sapi Jabres yang dilakukan oleh kedua KTT tersebut relatif sama, yakni dengan mengandangkan sapisapinya di kandang komunal yang terletak disatu kompleks, dan tidak menjadi satu dengan rumah pemilik. Tanah yang digunakan untuk kandang berada di pinggir hutan milik perhutani dan jauh dari pemukiman penduduk (KTT Cikoneng Sejahtera), sedangkan kan- 
Tabel 1. Profil kelompok tani ternak Cikoneng Sejahtera dan Lembu Lestari di Kecamatan Bandarharjo, Kabupaten Brebes

\begin{tabular}{lll}
\hline \multicolumn{1}{c}{ Uraian } & \multicolumn{1}{c}{ KTT Cikoneng Sejahtera } & \multicolumn{1}{c}{ KTT Lembu Lestari } \\
\hline Waktu berdiri & Februari 2008 & Februari 2006 \\
Kedudukan & Desa Malahayu & Desa Cikuya \\
Jumlah anggota, orang & 49 & 63 \\
Jumlah ternak, ekor & 317 & 309 \\
Kepemilikan, ekor/orang & $2-14$ & $1-11$ \\
Pengalaman beternak, tahun & $5->20$ & $7->20$ \\
Pendidikan peternak & Tidak sekolah - sarjana & Tidak sekolah - SLTP \\
Mata pencaharian & Petani $(98 \%)$ & Petani (100\%) \\
\hline
\end{tabular}

dang sapi milik KTT Lembu Lestari berlokasi di tepi sungai yang melewati Desa Cikuya. Tipe kandang yang digunakan terbuka yaitu di sekeliling tidak ada dinding penutup, terbuat dari kayu atau bambu dengan atap dari gentingdan sudah dilengkapi dengan palung pakan yang terbuat dari bambu dan ember sebagai tempat minum. Lantai kandang berupa tanah yang dipadatkan. Ukuran kandang sangat bervariasi tergantung dari banyaknya kepemilikan ternak. Sapi ditempatkan saling berhadapan (head to head). Potret perkandangan sapi Jabres di kedua KTT ini sama dengan perkandangan sapi Jabres secara umum di Kabupaten Brebes sebagaimana dilaporkan oleh Oktavianto (2013).

Pemberian pakan sapi-sapi milik kedua KTT tersebut dilakukan dengan 2 (dua) cara yaitu digembalakan pada siang hari selama 8-10 jam (pukul 07.00-17.00). Pengembalaan dilakukan di hutan-hutan milik perhutani, di sawah yang sedang tidak ditanami atau di tempat lain yang terdapat rumput liar. Pada malam hari sapi dikandangkan, namun masih juga diberi pakan. Pengembalaan khususnya dilakukan pada musim kemarau, sedangkan pada musim penghujan sebagian ternak justru dikandangkan untuk mencegah kerusakan jalan desa akibat pengembalaan tersebut. Jenis pakan yang diberikan dalam kandang berupa rumput liar, jerami padi, jerami jagung (KTT Cikoneng Sejahtera), dan ada yang memberikan rumput Gajah hasil tanaman sendiri (KTT Lembu Lestari), sesuai dengan ketersediaan bahan pakan tersebut. Pakan konsen trat tidak pernah diberikan oleh peternak di kedua KTT tersebut. Air minum diberikan sebelum dan sesudah sapi-sapi digembalakan.

Perkawinan sapi Jabres di kedua KTT terjadi secara alami, khususnya ketika ternak digembalakan, sehingga peran peternak sangat kecil. Peternak tidak mengatur kapan sapi harus dikawinkan pertama kali ataupun memilih pejantan yang digunakan untuk mengawini ternak-ternak tersebut. Kerugian dari perkawinan seperti ini adalah ternak-ternak yang masih belum dewasa tubuh sudah akan bunting sehingga anak yang dilahirkan pun akan mempunyai kualitas yang jelek. Selain itu kemungkinan terjadinya inbreeding sangat tinggi. Pola perkawinan alami juga terjadi pada pemeliharaan sapi Jabres secara umum di Kabupaten Brebes (Oktovianto, 2013), namun hasil penelitian tersebut menunjukkan adanya perkawinan alami dengan pejantan tertentu $(12,67 \%)$. Hal itu menunjukkan bahwa peternak sudah ikut campur tangan dalam perkawinan melalui pemilihan pejantan yang digunakan untuk mengawini ternaknya.

Pemeliharaan sapi Jabres betina yang sedang bunting maupun menyusui anak tidak diberi perlakuan khusus. Sapi betina yang sedang bunting tetap saja digembalakan seperti sapi-sapi yang lain. Perlakuan khusus diberikan pada induk yang akan melahirkan ditempatkan secara terpisah. Induk dibiarkan melahirkan secara alami, hanya disediakan air minum. Induk yang telah melahirkan tidak digembalakan selama satu bulan sampai anaknya kuat berjalan. 


\section{Sistem Produksi dan Produktivitas Sapi Jabres.}

Hasil penelitian menunjukkan bahwa hampir semua peternak (98\%) memelihara sapi untuk mendapatkan anak yang dapat dijual apabila sewaktu-waktu membutuhkan dana bagi kepentingan keluarga. Tujuan pemeliharaan ternak sapi Jabres pada KTT ini sama dengan tujuan usaha ternak sapi potong rakyat Indonesia pada umumnya yaitu untuk tabungan yang sewaktu-waktu dapat di-gunakan untuk kepentingan yang mendesak sebagaimana dinyatakan oleh Soekardono (2005), Luanmase et al. (2011) dan Sonbait et al. (2011). Tidak ada anggota KTT yang memelihara sapi khusus untuk usaha penggemukan. Hal ini dibuktikan dengan sebagian besar sapi yang dipelihara di kedua KTT adalah sapi betina dewasa $(41,80 \%$ KTT Cikoneng Sejahtera dan 41,10\% KTT Lembu Lestari). Kenyataan ini menunjukkan bahwa sistem produksi sapi Jabres yang diterapkan di KTT Cikoneng Sejahtera dan Lembu Lestari adalah sistem produksi induk dan anak (cowcalf system). Sistem produksi induk dan anak merupakan sistem produksi untuk menghasilkan anak-anak sapi lepas sapih untuk program selanjutnya (Blakely dan Bade, 1998). Menurut Arfa'i et al. (2009), saat ini usaha peternakan untuk menghasilkan sapi bakalan dalam negeri (cow-calf operation), 99\% dilakukan oleh peternakan rakyat. Di kedua KTT, anak-anak sapi yang dilahirkan dipelihara bersama-sama dengan induknya sampai disapih secara alami yaitu ketika anaknya berumur 7-8 bulan.

Dijelaskan oleh petani peternak, bahwa ketika anak sapi berumur 2-3 bulan, biasanya induk sudah menunjukkan tanda-tanda berahi, dan segera akan terjadi perkawinan ketika ternak digembalakan. Hal ini menjadi indikasi bahwa calving interval (jarak beranak) sekitar 12 bulan. Jarak beranak yang terjadi, sesuai dengan pendapat (Aryogi et al., 2007), yaitu sekitar 11-14 bulan dan jarak beranak yang pendek merupakan salah satu keunggulan sapi Jabres. Sistem produksi induk anak pada sapi Jabres yang terdapat di Kecamatan Bandarharjo sesuai dengan hasil penelitian Munadi (2010) bahwa sebagian besar pola usaha sapi Jabres di Kabupaten Brebes adalah untuk menghasilkan pedet (anak sapi), sedangkan untuk usaha penggemukan hanya $6,1 \%$ dan sisanya $12 \%$ adalah usaha campuran atau kombinasi antara menghasilkan pedet dan penggemukan.

Rata-rata pertambahan bobot badan harian $(\mathrm{PBBH})$ anak-anak sapi yang belum sapih (umur 1-4 bulan) sebesar 0,29 $\pm 0,15 \mathrm{~kg}$, sedangkan $\mathrm{PBBH}$ anak-anak sapi yang lepas

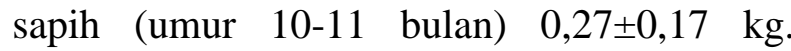
Produktivitas anak-anak sapi yang diukur dari PBBH sangat dipengaruhi oleh pakan yang diberikan. Induk sapi yang sedang bunting maupun menyusui tidak mendapatkan perlakuan pemberian pakan secara khusus, artinya pola pemeliharaan dengan sistem semi-intensif yang dilakukan dengan cara pengembalaan dan penambahan pakan di kandang pada sore hari, menghasilkan PBBH anak sapi baik sebelum sapih maupun setelah sapih yang cukup baik. Hasil penelitian Lestari et al. (2009) tentang status nutrisi sapi Jabres di kedua KTT menunjukkan bahwa sapi-sapi yang dipelihara hanya dengan cara digembalakan, memperoleh nutrisi yang rendah sehingga hanya cukup untuk pokok hidup, tetapi sapi-sapi yang dipelihara dengan cara dikandangkan dan mendapat pakan jerami jagung, maka pakan tersebut mampu mencukupi kebutuhan untuk produksi, meskipun rendah, karena kualitas jerami jagung yang diberikan cukup baik. Berdasarkan hasil penelitian Lestari et al. (2009) tersebut, maka pakan yang diperoleh induk bunting dan menyusui dengan cara pemeliharaan siang digembalakan dan malam hari dikandangkan dan diberi tambahan pakan kasar sesuai dengan ketersediaan pakan tersebut ternyata mencukupi kebutuhan untuk induk menyusui, meskipun lebih baik apabila ada perlakuan pakan khusus untuk induk menyusui, misalkan diberi konsentrat, agar anak-anak tumbuh dengan lebih baik.

\section{KESIMPULAN}

Kesimpulan dari hasil penelitian ini adalah sistem produksi yang dilakukan oleh sebagian besar (98\%) petani peternak anggota KTT di Kecamatan Bandarharjo Kabupaten 
Brebes merupakan sistem produksi induk anak. Adapun produktivitas anak sapi sebelum dan lepas sapih yang diukur dengan $\mathrm{PBBH}$ cukup baik yaitu $0,29 \pm 0,15 \mathrm{~kg}$ dan $0,27 \pm 0,17$ kg. Perlu dilakukan perbaikan pakan (dengan penambahan konsentrat) khususnya untuk induk bunting dan menyusui, agar anak sapi yang dihasilkan mempunyai produktivitas yang tinggi.

\section{DAFTAR PUSTAKA}

Arfa'i, K. Wardhono, A. M. Fuah dan A. Syaefuddin. 2009. Potensi pengembangan usaha sapi potong dalam sistem usahatani di Kabupaten Limapuluh Kota Sumatra Barat. Jurnal Pengembangan Peternakan Tropis 34(1): 65-73.

Aryogi, E. Romjali, Mariyono, dan Hartati. 2007. Karakteristik plasma nutfah sapi potong lokal Indonesia. Laporan Penelitian. Badan Penelitian dan Pengembangan Pertanian, Grati.

Blakely, J. dan D. H. Bade. 1998. Ilmu Peternakan. Edisi Keempat. Gadjah Mada University Press, Yogyakarta.

Dinas Peternakan Propinsi Jawa Tengah dan BPTP. 2005. Inventarisasi sumber daya hayati ternak lokal Jawa Tengah. Laporan Penelitian. Balai Pengkajian Teknologi Pertanian, Jawa Tengah

Lestari, C. M. S., Soedarsono, E. Pangestu dan A. Purnomoadi. 2009. Status nutrisi sapi Jawa yang dipelihara petani peternak Kecamatan Bandarharjo, Kabupaten Brebes. Prosiding Seminar Teknologi Peternakan dan Veteriner. 13-14 Agustus 2009. Hal: 269-274. Pusat Penelitian dan Pengembangan Peternakan, Badan Penelitian dan Pengembangan Pertanian, Bogor.

Lestari, C. M. S., Soedarsono, E. Pangestu dan A. Purnomoadi. 2010. Carcass production of Jawa Cattle raised under traditional management. Proceedings International Seminar on Prospects and Challenges of Animal Production in
Debeloping Countries in the $21^{\text {st }}$ Century. Faculty of Animal Husbandry, University of Brawijaya, Malang. Malang, 23-35 March 2010. Hal: OP-34 - OP-37.

Lestari, C. M. S. 2012. Explorasi potensi produksi sapi Jabres sebagai sapi Potong Lokal dengan metode in vivo dan Noninvasive pada pemeliharaan In situ dan ex situ. Disertasi. Program Studi Doktor Ilmu Peternakan, Program Pasca Sarjana Universitas Diponegoro, Semarang

Luanmase, C. M., S. Nurtini dan F. T. Haryadi. 2011. Analisis motivasi beternak sapi potong bagi peternak lokal dan transmigran serta pengaruhnya terhadap pendapatan di Kecamatan Kairatu, Kabupaten Seram Bagian Barat. Buletin Pet 35(2): 112-122.

Munadi. 2010. Potensi dan alternatif pengembangan Sapi Jawa khas Brebes (Jabres). Prosiding Seminar Nasional Perspektif Pengembangan Agribisnis Peternakan di Indonesia. 10 April 2010, hal.348-353. Fakultas Peternakan Universitas Jenderal Soedirman, Purwokerto.

Oktovianto, H. P. 2013. Analisis faktor-faktor yang mempengaruhi pengembangan usaha ternak sapi Jawa Brebes (Jabres) di Kabupaten Brebes. Tesis. Program Studi S2 Fakultas Peternakan dan Pertanian Universitas Diponegoro, Semarang.

Rouse, J. E. 1976. Cattle of Africa and Asia. World Cattle II. CSIRO-Pusat Penelitian dan Pengembangan Peternakan, Ciawi, Bogor.

Soekardono. 2005. Kontribusi usaha ternak sapi terhadap pendapatan dan distribusi pendapatan petani di daerah persawahan irigasi (Kasus di Desa Sukowiyono, Kecamatan Padas, Kabupaten Ngawi). Buletin Pet 29(4): 193-199.

Soeroso dan E. Kurnianto. 2006. Karakteristik fenotif warna bulu pada Sapi Jawa. Jurnal Agrisains, 7 (1): 52-58. 
Sonbait, L. Y., K. A. Santosa dan Panjono. 2011. Evaluasi program pengembangan sapi potong gaduhan melalui kelompok lembaga mandiri yang mengakar di masyarakat di Kabupaten Manokwari,
Papua Barat. Buletin Pet 35(3): 208-217. Sutopo, K. Nomura, Y. Sugimoto, dan T. Amano. 2001. Genetic relationship among Indonesian Cattle. J. of Animal Genetic 28 (2): 3-11. 